\title{
EHMTI-0080. How migraine is affected by therapies for multiple sclerosis
}

\author{
C Condello*, L Pinessi, L Savi \\ From 4th European Headache and Migraine Trust International Congress: EHMTIC 2014 \\ Copenhagen, Denmark. 18-21 September 2014
}

\section{Introduction}

There are a number of available disease-modifying therapies for Multiple Sclerosis (MS). Prevalence of migraine is higher in SM patients than in the general population, so possible effects of these preventive treatments on migraine should be monitored. A review of the literature on the subject is presented.

\section{Methods}

PubMed, Ovid and Google Scholar searches were conducted looking for Migraine combined with Beta-Interferon (bIFN), Glatiramer Acetate (GA), Natalizumab, Fingolimod, Laquinimod, Teriflunomide, Azathioprine, Methotrexate, Mitoxantrone and Ciclofosfamide.

\section{Results}

Use of bIFN-1a was related to worsening of previously diagnosed migraine $(37,5-41 \%, \mathrm{p}<0.05)$ and to high percentage of de novo headache presentation (41-44\%, $\mathrm{p}=0.05,1 \frac{1}{4}$ of which with migraine features).

GA was associated with only $11 \%$ of worsening of migraine, and a direct comparison with bIFN showed the latter as much more migraine-inducing.

Effects of Natalizumab on migraine were evaluated in a small sample, but a significant reduction in migraine frequency and MIDAS scores was detected.

Only spurious cases of worsening of migraine were reported with use of Fingolimod.

\section{Conclusions}

Of all disease-modifying therapies used in MS, bIFN is the only one which showed a clear association with worsening of previous migraine. Interpretation of data is difficult on increased incidence of migraine after starting a diseasemodifying treatment, due to uneasy distinction between

Headache Center, Città della salute e della scienza, Torino, Italy facilitation of a true migraine and secondary headache, attributable to medications.

Migraine should always be carefully assessed in patients affected by MS, in particular if treated with disease-modifying medications, to evaluate eventual modification of migraine itself.

No conflict of interest.

Published: 18 September 2014

doi:10.1186/1129-2377-15-S1-D11

Cite this article as: Condello et al.: EHMTI-0080. How migraine is

affected by therapies for multiple sclerosis. The Journal of Headache and Pain 2014 15(Suppl 1):D11.
Submit your manuscript to a SpringerOpen ${ }^{\circ}$ journal and benefit from:

- Convenient online submission

- Rigorous peer review

- Immediate publication on acceptance

Open access: articles freely available online

- High visibility within the field

Retaining the copyright to your article 